DOI https://doi.org/10.30525/978-9934-26-046-9-46

\title{
СУЧАСНІ ВИМОГИ ДО ПЛАНУВАЛЬНИХ РІШЕНЬ ТОРГОВОГО ПРОСТОРУ АВТОЗАПРАВНИХ КОМПЛЕКСІВ
}

\author{
Зигун А. Ю. \\ кандидат технічних наук, \\ доиент кафедра будівництва та иивільної інженерії \\ Національний університет «Полтавська політехніка \\ імені Юрія Кондратюка» \\ Авраменко Ю. О. \\ кандидат технічних наук, \\ доичент кафедра будівництва та ичивільної інженерії \\ Національний університет «Полтавська політехніка \\ імені Юрія Кондратюка» \\ м. Полтава, Україна
}

Під час бурхливого зростання будівництва стаціонарних автозаправних комплексів, магазин супутніх товарів при автозаправній станції стає важливою конкурентною перевагою, яка дозволяє не тільки залучити додаткових покупців на АЗК, а й отримати прибуток від самого сервісу. Частка товарообігу в пристанційному магазині супутніх товарів може становити до $20 \%$ від загального обороту комплексу. Не останню роль в досягненні такого результату відіграє точна організація торгового простору.

Однією з важливих складових концепції магазину при АЗК $є$ технологічне планування, тобто сукупність всіх приміщень торгового підприємства в певному взаємозв'язку, що забезпечує найбільш раціональну організацію оперативних процесів.

Технологічне планування - першочергова умова створення або реконструкції магазину на території автозаправного комплексу, що дозволяє максимально ефективно використовувати наявні торгові площі. Завдання полягає в тому, щоб змусити працювати кожен квадратний метр площі з найбільшою віддачою[1].

Щоб вірно спроектувати простір торгового залу на АЗК, потрібно перш за все визначити його форму і загальну площу. Прямокутний простір - найбільш зрозумілий, простий і зручний в плані ефективно- 
сті розміщення конструкцій. Торгівельна площа округлої або овальної форми ускладнює підбір і розміщення вітрин, полиць, стелажів.

«Вірне» планування торгового залу магазину на АЗК повинно забезпечувати:

- проходження покупців по всій площі торгового залу;

- зручність орієнтації і пересування покупців в торговому залі;

- ефективне зонування - розподіл місць для різних товарних категорій з тим, щоб досягти їх максимальної економічної ефективності;

- ефективне розташування торгового обладнання;

- емоційний комфорт для покупців, що сприяє підвищенню числа покупок.

Необхідно визначити основні зони торгового залу, розподілити товарні категорії або бренди в торговому залі і скласти план розташування торгового обладнання. Від розмірів торгового залу і зручності планування багато в чому залежать пропускна спроможність магазину і обсяг його товарообігу[2].

У торговому залі можна виділити три основні зони:

- вхідна зона;

- касова зона;

- зона основного потоку покупців.

За типом планування торгові зали поділяють: решітка, петля, лабіринт.

Ці три види планування $є$ базовими при проектуванні, проте на практиці використовують поєднання двох або трьох видів планування[3].

Вид планування залежить від площі магазину, цінового рівня (формату) і асортименту. Головне при цьому забезпечити:

- зручність орієнтації і пересування покупців в торговому залі;

- прохідність купівельного потоку у всіх зонах магазину;

- прозорість торгового залу (в невеликих магазинах - повну, в великих - зональну).

Планування вважається вдалим, якщо досягнуто рівновагу між комфортом для покупців і ефективним використанням торгового простору. Для більшості магазинів ефективність використання площ можна визначити за допомогою узагальненого коефіцієнта установчої площі (відношення площі обладнання до загальної площі торгового залу, що складає від 0,25 до 0,35 ) [4].

Коефіцієнт установчої площі наближається до нижньої межі для магазинів типу петля - 3 дорогими товарами і невеликою торговою площею. 
Коефіцієнт установчої площі наближається до своїх максимальних значень для магазинів економ-класу невеликої площі, де безліч дешевих товарів повинні мати високу оборотність для досягнення фінансової ефективності.

В цілому завантаженість торгових залів обладнанням залежить від рівня доходу цільових покупців: чим вище рівень доходу, тим більше вільного простору і менше обладнання в залі; чим нижче рівень доходу, тим більше торгового обладнання та товару представлено в залі.

\title{
Лiтература:
}

1. Тютюнник Я. С. Аналіз розміщення АЗС на автомобільних дорогах I категорії // Вісник Національного транспортного університету. К. : НТУ, 2013. Вип. 28. С. 472-476.

2. Шалай В.В. Проектирование и эксплуатация нефтебаз и АЗС : учебное пособие / В.В. Шалай. - Омск: Изд-во ОмГТУ, 2010. - 296 с.

3. Волгушев А.Н. Автозаправочные станции. Оборудование. Эксплуатация / А.Н. Волгушев, А.С. Сафонов, А.И. Ушаков. - СПб.: ДНК, 2001. - $176 \mathrm{c}$.

4. Коршак А.А. Нефтебазы и АЗС : учебное пособие / А.А. Коршак, Г.Е. Корабейников, Е.М. Муфтахов. - Уфа: Дизайн полиграф сервис, 2006. -416 с.

DOI https://doi.org/10.30525/978-9934-26-046-9-47

\section{ІНФОРМАЦІЙНІ ТЕХНОЛОГІЇ МОДЕЛЮВАННЯ ЖИТТЕВОГО ЦИКЛУ БУДІВЕЛЬ ТА СПОРУД}

\author{
Іванова Л. С. \\ кандидат технічних наук, доцент, \\ доиент кафедри нарисної геометрії та інженерної графіки \\ м. Київ, Украӥна
} Київський національний університет будівництва і архітектури

Життєвий цикл будь-якого архітектурно-будівельного об'єкту або споруди включає ряд етапів і регламентується законодавством, технологічними особливостями цього процесу та інформаційним наповненням. 